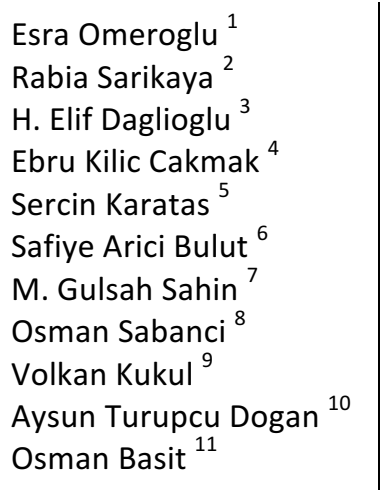

\section{The Terms Used in Gifted and Talented Education in Turkey, Relevant Legal Framework and Educational Practices}

\begin{abstract}
Giftedness/talentedness is one of the areas that is not fully defined yet, and its meaning and scope are highly debated in parallel with the concept of intelligence. Discussions about how giftedness/talentedness can be conceptualized, identified, supported and predicted are still ongoing. The concept of giftedness/talentedness and the initial studies on the education of talented and gifted pupils seem to extend to Plato. In this study, firstly the definitions of leading names in the field about giftedness were examined and then field-specific terms were tried to be described. Many documents especially The Constitution of Turkish Republic, laws, decree laws, by laws, circulars and the Convention on the Rights of the Child have been examined in relation to the topic. In terms of the practices in the field of education, the Ottoman Empire period was briefly reviewed and information about the practices in Turkey was given. As a result, despite all the work mentioned, it has been found that there are various problems in the education of gifted and talented children and in supporting their skills. In order to solve the problems experienced by talented and gifted children in Turkey, it is necessary to develop a government policy regarding the education of talented and gifted children.
\end{abstract}

Keywords: Talented and gifted education, definition of talented and gifted, educational studies on talented and gifted education in Turkey

\section{Introduction}

It can be said that we owe the civilization achieved from prehistoric ages until today, outstanding developments in the fields such as science, art, technique, fine arts, thought and etc. to those who are creative, determined and gifted/talented people with the positive and negative aspects.
Some countries have developed policies to educate and employ gifted/talented people, being aware of this significant potential in their own hands. In this context, the definitions that are accepted as universal in relation to this concept of gifted/talented individuals in Turkey, the legal framework and the educational practices are discussed.

\footnotetext{
${ }^{1}$ Ph.D., Prof., Pre-school Education Department. Gazi University, Ankara, TURKEY.

2 Prof. Dr. Classroom Education Department, Gazi University, Ankara, TURKEY.

${ }^{3}$ Ph.D., Assoc. Prof., Pre-school Education Department, Gazi University, Ankara, TURKEY. e-mail: edaglioglu1@gmail.com

${ }^{4}$ Ph.D., Assoc. Prof., Education of Computer and Instructional Technologies Department, Gazi University, Ankara, TURKEY.

${ }^{5} \mathrm{Ph}$. D., Assoc. Prof., Education of Computer and Instructional Technologies Department, Gazi University, Ankara, TURKEY

${ }^{6}$ Ph.D., Asst. Prof., Guidance and Psychological Counseling Department, Gazi University, Ankara, TURKEY.

${ }^{7}$ Ph.D., Lecturer, Assessment and Evaluation in Education Department, Gazi University, Ankara, TURKEY.

${ }^{8}$ Ph.D., Res. Asst., Education of Social Studies Department, Gazi University, Ankara, TURKEY.

${ }^{9}$ Res. Asst., Education of Computer and Instructional Technologies Department, Gazi University, Ankara, TURKEY.

${ }^{10}$ Res. Asst., Pre-school Education Department, Gazi University, Ankara, TURKEY.

${ }^{11}$ Res. Asst. Pre-school Education Department, Gazi University, Ankara, TURKEY.
} 


\section{Definitions and Terminology Used about Giftedness/Talentedness}

Giftedness/talentedness is one of the areas that are not fully defined yet whose meaning and content are highly debated in parallel with the concept of intelligence. However, diversity in the area of giftedness/ talentedness is very high. Gifted/talented individuals may be universally encountered in all cultures, ethnic and socioeconomic groups. However, debates about how giftedness/talentness can be conceptualized, diagnosed, supported and predicted are still ongoing (Sternberg, 2007).

In the historical process, the first studies about the concept of giftedness/talentedness and the education of gifted/talented individuals seem to extend to Platon. They had been defined as "Their memory are strong. They do not be easily mistaken. They have robust and reasonable jurisdiction." in the book written by Platon about the idealistic organization of the society which is necessary for the administration of the societies and the election and training of the administrators (Enç, 1979). The education system that Platon proposed to educate diplomats was firstly put into practice by Ottoman Empire with the "Palace Schools" (Akkutay, 1984; Enç, 1979; Özsoy, Özyürek and Eripek, 1989).

Some countries have developed policies to educate and employ gifted/talented people in recognition of the significant potential in their hands. In this regard, the common definitions, legal framework and educational practices about gifted/talented people in Turkey are discussed.

Until the establishment of the Republic of Turkey from the Ottoman Empire, there is no featured study about gifted/talented people. In this process, studies conducted mostly in Europe and America are drawing attention. After these studies, it can be said that most of the definitions about giftedness/talentedness are accepted in our country, too. These definitions are briefly mentioned below.

According to Terman (1925), who is one of the pioneers of this field, those who score at the upper limit of $1 \%$ in standard intelligence tests should be described as "gifted". However, from the middle of the 20th century, this definition has begun to fell from favor as a result of intelligence becoming a concept that involves many talents (Akarsu, 2001).

According to the Marland report, published in the United States in 1972, gifted/talented children were defined as "Children who perform well in one or more of these six areas, including general mental ability, special ability in a certain academic field, creative and productive thinking, leadership ability, talent in visual performing arts, and psychomotor ability".

Renzulli (1986), one of those who came to the fore after this definition of the Marland Report, reviewed the successful figures and proposed the triple circle model. In the triple circle model, it has been suggested that children should have a certain level of performance on each of the three basic dimensions of ability, creativity and motivation over normal. Gardner (1983; 1991), who is contemporary with Renzulli, has brought a different perspective to intelligence with the theory of multiple intelligences. Gardner has shown that intelligence can not be assessed in a single dimension, that is, only verbally or only numerically, and that it must be also discussed in different dimensions. Correspondingly, according to Gardner, intelligence is the capacity to solve problems and create new products and new solutions by overcoming problems experienced in different situations and incidents in life.

One of the studies to explain the concept of giftedness and talentedness belongs to Gagné. Gagné (1991) has drawn attention to the differences between giftedness and talentedness, describing giftedness as a power over the average of human ability, and talentness as a performance over the average on a specific area.

Morelock (1992) has defined giftedness/talentedness as "asynchronous (incompatible/nonsynchronous) development, that presents internal experiences qualitatively and quantitatively different from normal development standards and includes advanced cognitive abilities" by drawing attention to the developmental characteristics of gifted and talented children, particularly to preschool period, in which development is the fastest.

In 1991, the Ministry of National Education made the 1st Special Education Council in Turkey in parallel with the devel- 
opments in the identification and education of gifted and talented children in the world and adopted a definition similar to the definition of the American Education Commission. The gifted and talented child is defined as " $a$ child determined by specialists of the subject who perform at a high level in terms of her/his general and/or special abilities, according to her/his peers" (MoNE, 1991a). In addition, this definition has been updated as "Highly performing individual according to his / her peers in intelligence, creativity, art, sports, leadership capacity or special academic fields" in the Directorate of Special Education Services published in 2006 (MoNE, 2006a).

As a result, while drawing the conceptual framework of giftedness/ talentedness, different terms are used in Turkey as well as terms generally accepted in the world. These are;

Gifted: Individuals who have intelligence level above average at least two standard deviations in intelligence tests.

Gifted and talented children: It is the term used by The World Council for Gifted and Talented Children for individuals who are superior in the intelligence and/or talent areas and in addition, it is the most widely adopted term by many countries and specialists in the field.

Superior talent: It is the term used by some researchers, considering intelligence and special talents under the concept of "superior talent" and categorizing under six areas, general mental ability, special academic ability, creative and productive thinking ability, leadership ability, ability in visual arts and psychomotor skill.

Special talent: It is the term that has been started to be used by the Ministry of National Education in Turkey for gifted and talented children after 2010.

\section{Legal Framework}

In this section, notably the constitution, related legislation, statutory decrees, regulation, directions and child rights conventions current in Turkey, which are directed at gifted/talented individuals were examined. It was also mentioned how the subject is addressed in development plans and National Education Councils in the country.

\section{Constitution}

The first law that treats gifted / talented individuals as a right to benefit from both general and special education is the 1924 Constitution. In this Constitution, Article 80 stated that "All types of education is free under the supervision and control of the government and under the law" and Article 87 stated that "Both males and females, all Turkish people are obliged to pass primary education. Primary education is free of charge in public schools." Then in Article 50 of the Constitution of 1961 stated that "The State takes measures for people in need of special education due to special circumstances to make them beneficial for the society. The provision of all kinds of conditions to ensure the best position of the gifted/talented individuals in need of special education is under state guarantee.", by this statement, the right to education of gifted and talented children has been taken under protection (Çetinkaya and Döner, 2012; Kili and Gözübüyük, 2000). Similarly, the right to education of these children continued to be preserved in Article 42 of the 1982 Constitution of the Republic of Turkey, "... The State takes measures for people in need of special education due to special circumstances to make them beneficial for the society. Education and training institutions only conduct activities related to education, teaching, research and investigation. These activities can not be prevented in any way." (Akyüz, 2008).

\section{Convention on the Rights of the Child}

Provisions related to child education are present in Articles 28, 29 and 30 of the first part of the "Convention on the Rights of the Child", which emphasizes the necessity of providing the minimum care to all children in the world. For example, in Article 29, paragraph 1 , sub clause $a$, expressions such as "The development of child's personality, talents, mental and physical abilities as far as possible" are involved (Kepenekci, 2014). In this declaration, all children are mentioned about the benefits of good living, education, and for gifted/talented children the expression, "Gifted children must be brought to the widest means and opportunities of growth 
with the help of the state and their families" is included (Çetinkaya, 1998; Turupcu and Gültekin Akduman, 2015).

\section{Laws}

The first regulation on gifted/talented students in the Republic period was the Law No. 1416, "Law on Students to be Sent to Foreign Countries" accepted on 8.4.1929. According to this law, an exam is being organized by the Ministry of National Education (Official Gazette, 1929:2) in order to determine students who differ in intelligence and other skills from other students to send students abroad at secondary and higher education level every year. According to this law, scholarships are given every year for high school graduates and those who have graduated from various branches of higher education by the Ministry of National Education and in order to provide education in the western countries by choosing those who want to study specializing in State or Economic State Organizations (MoNE, 2010a:13). This application has been expanded by the Law No. 4489 on "Law on Officers to be Sent to Foreign Countries", which was enacted in 1943 (Official Gazette, 1943:1).

Another legal regulation was the Law No. 5245, related to "Delivery of Îdil Biret and Suna Kan to Music Collection of Foreign Countries" prepared by the Minister of National Education Hasan Ali Yücel and published in July 12, 1948 (Ataman, 2014). With this law, education of Îdil Biret and Suna Kan in foreign country, who have achieved extraordinary success in the field of music, was regulated (Official Gazette, 1948:5).

Law No. 6660 issued in 1956, "Law on the Raising Children Displaying Extraordinary Ability in Fine Arts" expanded the content of application of the previous law. This law regulated the process of raising children who were extraordinarily talented in the fine arts in the name of the state both inside and outside the country (Official Gazette, 1956:1). Due to the fact that the mentioned law could not be implemented in time, a commission was established by the Ministry of National Education and Culture, and in 1976 the "Special Statute Regulation" was issued which allowed intensive education for special talented children in the State Conservatory. Thanks to this regulation, many people with superior ability in the field of music have been educated abroad (MoNE, 2010a).

Another law establishing the legal basis for gifted/talented students was the Law No. 222, "Primary Education and Education Law". In the 12th article of this law, the statement, "Children who are mentally, physically, spiritually, and socially disabled are provided with special education and training in case they are in the age of compulsory primary education" was included (Official Gazette, 1961:13).

Regulation on the subject has been made in the 2nd, 6th and 8th articles of the "National Education Basic Law" No. 1739. The common point of these articles was pointing out social aspects, proper guidance services and equal opportunity of education (Official Gazette, 1973:1). In Article 2, "Raising people having a balanced and proper personality that has developed physically, mentally, morally, spiritually and emotionally; having independent and scientific thinking power, having a wide world view, being respectful to human rights, giving value to personality and character, being responsible towards society, being constructive, creative and productive.", in Article 6 "People raised by various programs or schools to the extent and in the direction of their interests, abilities and skills during their education", and in Article 8, "Special measures are taken to educate children in need of protection and special education " phrases were included.

Another legal regulation was the Law No. 2916 on "Children in Need of Special Education". Article 8 of this law stated that "Official and private primary and secondary schools are obliged to provide special education services for children in need of special education in their own environment" (Official Gazette, 1983).

\section{Statutory Decrees}

"Statutory Decree" no. 573 was issued with the aim of regulating the principles of special education related to the disabled people and published in the Official Gazette on June 6, 1997. There were expressions on the 2 nd, 4th, 7th and 8th Articles of this Decree (Official Gazette, 1997: 1-3).

The scope of special education services was stated in Article 2, and in Article 4, it was stated that education services would be presented in the direction of special education 
principles such as the right to education, earliness, proximity, continuity, individuality, family participation, interdisciplinary approach, interaction with society. After emphasizing in Article 7 that pre-school education was mandatory for individuals with special needs and that the education process could be extended when necessary, in Article 8 the institutions which individuals in special needs can continue were stated.

\section{Regulations}

The first regulation that took measures for the education of gifted / talented children was the "Regulation on Primary Education Institutions" enacted in 1961. In sub clause d of Article 117 of this regulation, some measures were mentioned, "in order to take necessary precautions and to provide new opportunities for the students whose special ability was determined to receive support education related to these fields, and to enable these students to improve themselves in cooperation with organizations such as the centers of Science and Art, Public Education Centers, Special Education Institutions, State Theaters, Provincial Culture Directorate, Youth and Sports Provincial Directorate, District Board of Scouting, Anatolian Fine Arts High School" (Official Gazette, 1961).

The concept was discussed in the first part of General Provisions, of the "Special Education Services Regulation", which was jointly issued by the Ministry of State and the Ministry of National Education in 2006, and in the same regulation in the Article 4 sub clause I, the support education room was defined as "Organized environment for the students who continue their education through inclusive educational practices and for the talented/gifted students to provide them supportive education services in the areas they need" (MoNE, 2006a).

In the second part of the regulation, the aims and basic principles of special education were specified. Accordingly, in Article 5 sub clause a, it was stated that "They should grow up as producers and happy citizens who fulfill their roles in the society, establish good relations with others, work collaboratively, adapt to their environment". Article 6 sub clause a stated that "All individuals in need of special education can benefit from special education services in line with their education and training needs, interests, abilities and qualifications "(MoNE, 2006a:28). In the 1st paragraph of Article 28, which contains the support education room which constitutes the subject of the third part of the same regulation, it was stated that "In the schools and institutions, for students in need with special education who continue their education in the same class with their peers who have no inadequacy, and for gifted/talented students, special tools and support education room will be provided as a special education support by providing education materials". In another regulation, statements relating to institutions opened for the education of gifted/talented individuals were included in paragraph 1 of Article 43. The stated expression was "Ministry of Education daytime special education institutions in order to ensure that the talented/gifted students of pre-primary, primary and secondary education period are aware of their individual abilities and use their capacities at the highest level by improving their capacities" and in sub clause b, it was "Social and emotional development is handled in unity "(MoNE, 2006a: 41).

In accordance with these regulations, in the 4th article of the Regulation on Pre-school and Primary Education Institutions in Turkey, support education room was defined as "The organized environment to provide supportive education services for children who are continuing their education through inclusive education applications and for gifted/talented children in areas they need.". The primary school was allowed to start one year early (60-66 months) under sub clause a, paragraph 6 of Article 11 of the same regulation. In addition, in the first paragraph of Article 32 of the same regulation, "Those who are above the grade level in terms of knowledge and skills of elementary school grade 1, 2 and 3 students are taken to the class upgrade examination within the first month of the education and training year with the recommendation of the class teacher and with family's written request. Successful students are upgraded to upper grade." phrase was stated. It is stated in the same paragraph that the test can only be done once for each child (Official Gazette, 2015). However, after the introduction of the $4+4+$ 4 education system, classroom upgrade was limited to primary schools only, and this application was not applicable at secondary and high school level (Bakioğlu and Levent, 2013). 


\section{Directive}

Various directives have been published with regard to the education and development of gifted and talented individuals as well as constitutional regulations. This subject was issued in "Science and Art Centers Directive (BILSEM)" which was published in the communiques of February 2007/2593 in the Articles $1,2,4,6,7,8,9,14,21,23,24,26,28$, 30,36 , and 43 . and in the sub-clauses.

For example, Article 1 states that "The aim of this directive is to ensure the awareness of gifted/ talented children/students in the pre-school, primary and secondary period about their individual abilities, providing their use of capacities at the highest level by improving their capacities and by this way, to organize the procedures and principles regarding the establishment and operation of the centers of science and arts which are opened and educated by the choice of teachers ". The content of this directive is defined as "The Directive covers the establishment, procedures and principles of science and art centers opened for the purpose of education and training of gifted/talented children/students affiliated to the Ministry of National Education". In Article 4 sub clause $j$, gifted/talented child/student was defined. In this directive, the formation, objectives and principles of Science and Art Centers, diagnosis and placement as well as teaching-learning and practical subjects were involved (MoNE, 2007). In addition to this, students are currently being elected to the BILSEM through the Directive on Science and Art Centers (Levent, 2014).

In order to prevent adverse situations that may arise in the absence of an appropriate orientation to children in need of special education, the importance of the need for guidance and psychological counseling services was emphasized in the Article $10 \mathrm{sub}$ clause i, published in 2003 with number 2552, "Guidance in Primary Education Directive". In order to draw under this importance, the following statements were given; "The Guidance and Psychological Counseling Service in the school, or otherwise affiliated with the Guidance Research Center, is cooperated to ensure that the gifted students and the students with special education need to be identified and directed in a proper way.".

\section{Five-Year Development Plans}

In Turkey, since 1963, development plans covering five years have been prepared considering total investments, total expenditures, demand situation in the country and saving tendencies in order for the country to show a planned growth. In these development plans, plans were also made for the education of gifted/talented children.

In the First Five-Year Development Plan, it was decided to create an education system that would distribute the citizens in various tasks according to their abilities, to provide scholarship to the students who are in need, and to make talented students benefit from all the educational opportunities regardless of their circumstances (SPA, 1963:449). In the Third Five-Year Development Plan, the decision has been taken on the application of an examination threshold in the transition to higher education and the reorganization of the examination system so that higher gifted/talented individuals can continue the higher education in the areas that they are capable of (SPA, 1973:751). In the Fifth Five-Year Development Plan, it was stated that necessary precautions should be taken for education of all children in need of special education and gifted/talented individuals, and necessary precautions should be taken to educate the teachers and staff to work in the field of special education. In addition, it has also been decided that special education services to be provided to gifted/talented children should be carried out within a program (SPA, 1979:157).

In the Sixth Five-Year Development Plan, it was decided that it was necessary to develop the infrastructure for education of all gifted and talented children along with all children with special needs, to reconsider and direct the free boarding and scholarship system to gifted/talented students with insufficient financial resources, and to educate these students as a scientist by making basic sciences desirable for them (SPA, 1990:294). In the Seventh Five-Year Development Plan, giving importance to the development of teachers and faculty members in terms of number and quality, developing the educational institutions for the education of gifted/talented and successful students and supporting the private sector initiatives in these fields were decided (SPA, 1996:41). In the Eighth Five-Year Development Plan, it was 
decided that the focus should be on inclusive education to ensure the flexibility of space, equipment, staff and programs to meet the needs of all children with special needs, and to provide guidance and counseling services for gifted and talented children in preschool and elementary school period, to prepare appropriate environment for the education of these children and to support initiations of private sector on this field (SPA, 2001:95), while in the Ninth Five-Year Development Plan, in addition to the decisions made in the previous development plan, the emphasis was placed on expanding the educational opportunities for qualified human power generation (SPA, 2007:6). In the 10th FiveYear Development Plan, which was the last development plan, it has been decided that the level of education and the quality of the labor force is a decisive factor in the labor movements with the emphasis on the increasingly qualified human power and that knowledge, communication technologies and education with intensive inter-cultural interactions will be multi-dimensionally enriched (SPA, 2012).

\section{Council Decisions}

In addition to the Development Plans, starting from 1921, issues related to the education of the gifted/talented children were discussed in the National Education Councils where the problems of the Turkish education system and the proposals regarding to their solutions were evaluated and the recommendations were taken. One of the decisions taken in the first Council stated in the book titled "National Education Councils (1995)" was "A ministry project on public schools was discussed. In this project, it has been stated that there is a need to prepare programs in order to educate children with a capability that can be successful in life. "(Cited by Sarıhan, 2009:104).

Firstly, the education of gifted/ talented children was mentioned in the 11th National Education Council in 1982. In this council, special education specialists were mentioned, whereas the education of gifted/talented individuals was also referred to as a special education field (MoNE, 1982:21). In 12th Council, again, it was recommended that education for gifted/talented children should be emphasized, special classes for children with high intelligence level should be opened, and programs for the education of gifted/talented children in science high schools should be included (MoNE, 1988:4). In addition, in 17th National Education Council, education of gifted/talented children were focused most. As a result of this council, the decisions;

- Making policies on education and employment of gifted children (Article 17);

- The education of these children being provided by teachers who have completed certificate programs for universities (Article 18);

- Recognizing the course credits of the activities and projects to be made in BILSEM as school course credits (Article 19);

- Student acceptance to Anatolian Fine Arts High School and Sports High School and similar secondary education institutions with twostage ability-based examination (Article 20);

- Opening institutions such as medallion schools, research units for these students that will be the attraction center, etc. The provide financial support to the families of students who will be going to these institutions (Article 21);

- Transitioning from a student-centered classroom system to a lecture-focused classroom system in primary and secondary education institutions' 6-12. grades and providing the opportunity for gifted and talented children to progress at their own pace (Article 22);

- Removal of prohibitive provisions on the entry of disabled students with special abilities into upper education institutions (Article 23);

- Selecting teachers for BILSEM with similar criteria used in the selection of teachers to be employed in Science high schools and Anatolian high schools (Article 24) and

- Being in a cooperation with TÜBITAK, the Ministry of National Education and the universities in the organization of summer and winter camps, science counseling and similar activities on education of gifted/talented students (Article 25) were taken (Ataman, 2014:16-17, MoNE, 2006b).

In the 18th National Education Council, decisions have been taken more indirectly concerning gifted/talented children. A few of these were related to the increasement of awareness of family and teachers in order guideline services to be carried out well, the effective use of different psychological measurement tools to guide orientation, and the monitoring of student performance in 
student orientation. In addition, the importance of developing valid and reliable diagnostic tools for the identification and detection of gifted/talented children has been addressed (MoNE, 2010b). The last National Education Council, 19th Council was held in 2014. As a result of this council, the proposals about the regulation of children's ability development from the pre-school period, the preparation of a regulation for the education of the talented/gifted students at high school level and the implementation of a new teaching program as valid from the kindergarten have been adopted (MoNE, 2014).

\section{Educational Practices}

It is not possible to not mention the "Palace Schools", one of the first educational facilities offered to gifted/talented children in history, while addressing the educational practices offered to them in Turkey. The Palace School, which was active during the Ottoman Empire, was the first educational institution in the world to systematically apply gifted/talented education. The Palace school can be considered as a school in palace where firstly the princes and talented slaves were educated from the time of Yıldırım Beyazıt II until the time of Murat II. Fatih the Conqueror has enlarged this school and restructured it to become a superior educational institution to educate the state servants (Enç, 1979; Enç, Çağlar and Özsoy, 1975; Güven, 2012; Kırpık, Ünal, Işık, Demirtaş, Tokdemir, Birbudak and Akyol, 2016).

The most elite of those who studied at Palace Schools had been assigned to important positions such as "Vizier, Grand Vizier, Governor, Chief Admiral". Many of the famous diplomats and commanders who passed through during Ottoman history grew up from this school with distinguished artisans, poets, and musicians (Akkutay, 1984; Akyüz, 2008). However, with the decline of the Ottoman Empire, the nature of the education in these schools began to move away from its purpose and the school was closed down by 1909. However, the Palace School system has been a source of inspiration for European educators and many countries have developed educational policies for gifted/talented individuals by taking advantage of this model. In this study, educational practices oriented towards the gifted and talented individuals were handled chronologically in the Republic of Turkey established after demolition of Ottoman Empire, the developments in the historical process were evaluated from various angles in discussion and conclusion section.

In the first years after the establishment of the Republic of Turkey, the country was in poverty and the literacy rate was very low, it was more and more necessary to take measures to solve these problems. However, shortly afterwards, the problem of lack of educated staff in modern education areas began to develop. In line with this need, 700 students with inadequate financial status had been sent to universities in America and European countries to study at various levels in higher education by Atatürk. They also served as senior executives in state-owned institutions when their training was completed and returned to the home country. These students were Remziye Hisar, Sabahattin Ali, Insan Ketin, Cahit Arf and many others who had superior successes in their fields. In 1929, Law No. 1416 on "Education Abroad" was enacted and applications for successful students to receive education abroad were made more regular (Ataman, 2014).

In 1961, a protocol was signed between the Ford Foundation and MoNE on the establishment of Science High School. In 1964, the first Science High School in Ankara was established and a special education was offered to children who showed outstanding achievement in mathematics and science. Ankara Science High School, which gave its first graduates in 1964, collected gifted/talented students in science and mathematics and teachers were educated with the financial support of Ford Foundation. Teachers were specially selected by the support of United States, Bronx and Science High School in New York and received special training with the teachers trained in the United States and in the Middle East Technical University. This implementation, supported by labs, books, trips, observations, discussions, small group works, and individual support practices in the boarding school environment, lasted for four years and began to lose its trait with the end of the support of the Ford Foundation. Currently more than 25.000 students attend the science high schools in 232 schools which are continuing to provide education (MoNE, 2015). 
In 1991, the First Special Education Council was organized by the Ministry of Education, gifted/talented children were also focused in this council, while there were no significant studies on gifted/talented children until 1990s. As a result of the council, the committee which also included faculty members who studied the relevant subjects has prepared a report about the definition, distinctive features of the gifted/talented children, the model drafting, diagnosis and selection, training programs and the application of these programs, employment, characteristics of educational environments for these children, current situation and problems in Turkey (MoNE, 1991a). In the same year, Yeni Ufuklar College was established and conducted studies on the education of the gifted/talented children in the primary school period. In this school, the importance of this issue in our country by maintaining connections with people related to foreign institutions had been tried to emphasized but the school was closed at the beginning of 2000s (Davaslıgil, 2004).

Again in 1991, Inanç Foundation was established in order to educate the gifted and talented children with limited financial resources under the leadership of businessmen Sezai Türkeş and Fevzi Akkaya and in 1993, Private Inanç High school started to provide boarding education with 300 students. This school, which served to secondary school and high school children continued to provide only high school education due to the fact that eight years of compulsory education was introduced in 1997. In 2002, the foundation was transferred to the Turkish Education Foundation because of financial impossibilities. Since 2002, it has been continuing to provide education in the name of Turkish Education Foundation İnanç Türkeş Private High School. In this high school, a program which is a combination of various teaching theories developed for special children at high school level is being conducted (Ataman, 2014; MoNE, 2010a).

Science and Art Councils (BILSEM), founded in 1995 are resource centers where gifted and talented students in pre-school, primary and secondary school age are educated in relation to their interests and abilities in times outside formal education. Science and Art Centers, which are the most prevalent institutions that provide education to the gifted/talented students in Turkey, have been planned to provide services to the gifted /talented students with the prepared program. Intelligence tests are applied to the BILSEM students and students who get over 130 points in intellectual capacity are accepted. There are 83 BILSEM in 70 cities in Turkey. In practice, BiLSEMs try to improve the students' well-being through enrichment of program and by integrating activities that will enable to consider students entirely as well as to develop emotional and social aspects with a curriculum (Özbay, 2013). However, although it is mentioned in the Directive of Science Art Centers, it is still not possible to start such an application for preschool children. BILSEMs are currently accepting students starting from primary school students. However, in order for BILSEMs to be the center of research, experimentation, observations and applications mainly by 2016, new strategies will be passed on by Ministry of National Education; in order to improve the quality of the education in BILSEMs, it was stated that workshops were organized with teachers, academicians and stakeholders, and event guides were prepared separately for each program (http://www.meb.gov.tr/ozelyetenekli-ogrenciler-icin-yeni-stratejilerhazirlandi/haber/9893/tr).

In 2002, for the first time in Turkey, in Istanbul University Hasan Ali Yücel Education Faculty and in 2010 in Maltepe University and then in Istanbul Aydin University, Biruni University and Sebahattin Zaim University, "Teaching of Gifted Children" undergraduate program was opened for the education of gifted/talented students. Anadolu University Education Faculty, Department of Special Education, the Division of Education of Gifted Children was also established and only the graduate level education is given here. In addition, educational and research centers have been established in Hacettepe, Inönü, Malatya, Kastamonu, Karabük, İstanbul Bilgi, Anadolu and Trakya Universities for the education of gifted and talented children. However, it is seen that Istanbul Medeniyet University has formed a Training Village for talented children by working together with Tuzla Municipality and that Sebahattin Zaim University is educating teachers about the education of gifted/talented children.

When examining the practices in our country in terms of pre-school education 
level, the applications made by Özel Petek Children's House in Istanbul are in the forefront. The Petek Children's House is a kindergarten where the gifted/talented ones are being diagnosed and provided accelerated and enriched experiences compared to the age groups. Furthermore, this school carries out special education programs with the parents of these children. The school, which receives information and experience support from various foreign organizations such as NAGE in the UK, also contributes to the efforts in our country by organizing scientific meetings and panels related to the subject (Akarsu, 2001).

In 2002, a study was initiated in Beyazit Ford Otosan Elementary School, which was conducted between MoNE and Istanbul University Hasan Ali Yücel Faculty of Education, in which a differentiated education program consisting of children with gifted/talented half of the class was developed. The aim was to educate gifted/talented children in terms of their talents, interests and capacities they need without leaving their normal peers (MoNE, 2010). This application ended with the adoption of Law No. 6287 on the $4+4+4$ education system, "Law on Primary Education and Education Law and Amendments in Some Laws" (Küçükoğlu, 2014).

Between 2007 and 2010, a group of academicians in Bursa conducted a project called "Identification and Education of the Gifted Children in Pre-school Age" in a private kindergarten. In the project, a model was adopted that offered a combination of enriched educational opportunities where highly talented children between the ages of 4 and 6 coexisted with their normal peers and at the same time had the opportunity to develop their skills and knowledge (Özbay et al., 2009). However, this application ended in 2011.

In addition, considering the preschool period, it is seen that the practices of inclusive education have come into prominence in recent years. In the Pre-School Education Program updated by the MoNE in 2013, it was explained how to adapt the activities according to the children in special needs in order to inform the teachers about inclusive education and facilitate the teaching practices. However, especially from the point of view of gifted/talented children, it has been observed that there were problems due to the graduation of teachers without knowledge and practice about diagnosis of these children (MoNE, 2013).

Another application is the Training Program of the Talented Professionals realized with the support of AAAS by the Head of Department of Education of the Gifted Ones of Anadolu University in the 2007-2008 education-training period. In this project, gifted and talented students in grades 6 and 7 are presented with an educational and social environment in which they discover their abilities, improve themselves and continue outside of the normal education-training process. In the program, gifted students are taught on weekends and summer terms using mathematics and science-based enrichment and acceleration strategies (Sak, 2009). It can be said that in addition to Anatolian fine arts schools, some of private schools which use highly selective and skeptical model and do not serve in direction of private education purposes, such as Robert College, Izmir American College, German and Austrian High School give education not only to students selected according to their success but also to a group of students who have special talents. However, especially in public schools, it is observed that especially the Anatolian high schools were spread out in an unplanned manner similar to the science high schools, and consequently the majority of their qualifications were decreased compared to the time they were first opened (Bakioğlu and Levent, 2013; Dağlıoğlu, 2015).

In 2009, with the collaboration of the Ministry of National Education and AAAS, it was started to work on establishing a strategy paper on the development of systems and activities related to the training of gifted/talented people. Regarding this, a workshop was held in 2009 aimed at evaluating the science and arts centers, determining the current situation, making comparisons with the world examples, and putting the applicability of the examples in line with the views of stakeholders in this context. In addition, at the 19th meeting of the Supreme Council for Science and Technology in 2009, the "Talented Individuals Strategy and Implementation Plan 2009-2013" was prepared in order to improve the education of the gifted/talented individuals in Turkey, and then the 2013-2017 plan was prepared (AAAS, 2013). In addition, 
AAAS provides awards to schools and students who succeed the project competition in the field of mathematics between primary school age students and provides services to 8-12 and 14-17 age groups by establishing the Academy of Gifted Students.

http://www.bursabilimmerkezi.org/sayfa/tubi tak-ustun-zekalilar-ve-yetenekliler-akademisi/ 61.htm). AAAS gives prizes to secondary school students who get a degree in secondary schools and high schools mathematics competitions, inter-high schools mathematics and biology competitions and project competitions between high school and university students, makes the rules for international mathematics and science olympics, creates Turkish team and prepares students for competitions, provides scholarships abroad for the purpose educating scientists (TGNA, 2012). Government Free-Boarding and Scholarships, which have been carried out since the foundation of the Republic, and assistance to students attending secondary and high school are also provided for the economic support of gifted/talented students.

In the 2013-2014 academic year, the Turkish Gifted and Talented Foundation established a school in Ankara with a differentiated and enriched program for the education of gifted / talented children, covering an age group from pre-school to secondary school (http://www.tuzyeksav.org.tr/). In addition, it is observed that private schools such as Tekden Schools, Doğa College and Bahçeşehir College have implemented programs to educate gifted/talented children within themselves.

In the Grand National Assembly of Turkey (TGNA), in November 2012, a research commission was established with the justification that is "The gifted and talented children are the greatest source of wealth in a country. Because they are the ones who will play the most important role in shaping the future of the country if they receive appropriate and adequate education. The policy of detection, education and monitoring of these children should be clearly defined and institutionalized and a continuing structure should be established." in order to find out the gifted and talented children, to find out the problems related to their education and to provide effective employment that will contribute to the development of country. As a result of the sub-commissioning studies, a com- prehensive report on the education of the gifted and talented children in Turkey, the problems and the solution proposal was prepared by examining the applications for the education of gifted/talented children in other countries (TGNA, 2012).

Three national and several international congresses and symposiums were held in our country, first one in 2004, regarding the education of gifted/talented children. The 4th national congress on the education of gifted/talented children will be organized in Hasan Kalyoncu University in Gaziantep in March 2017.

In Turkey, today, it is seen that over thirty civil society organizations such as the Turkish Foundation for the Education of the Gifted and Talented Children, the Federation of the Gifted Education, the Association of the Gifted and Talented Children, the Academic Association of the Gifted Children, the Tekden Association of the Education of the Gifted and Talented Children, the Foundation of Gifted Children have been established. Teachers, families, academicians and other interested people will come together to educate these children with a more organized approach for the education of gifted and talented children aimed at these non governmental organizations.

(http://www.tacved.org/ustun-yeteneklilericin-dernekler-vakiflar). The Federation of Higher Education of the Talented (FHET), on the other hand, aims to gather the associations supporting the education of the gifted and talented under a single roof, to exchange information on professional issues, to develop the relations with the private and official organizations that the members are interested in, to create ideas in cultural and social issues, lobbying activities, enlightening the public by making scientific researches on various issues included in FHET field of activity, and making the members and the country benefit from them by developing cooperation with similar national and international institutions (TGNA, 2012).

One of the important developments in this area is the Institute of Giftedness, which has been operating in Istanbul since 2000s. Since the day it was established, the institution has been educationg and providing corporate consultancy services for gifted/talented children, their families and teachers. However, it seems that many cen- 
ters such as Necate Baykok Gifted and Talented Institute, the Children's Foundation have been established to identify and educate the gifted/talented children. Turkish Gifted and Talented Journal (TGTJ), Young Scientist Education and Giftedness Journal and Education of Gifted Children and Creativity Journal (GCCJ) are three well-known journals about gifted/talented children in Turkey.

In addition to all these applications, some municipalities seem to have produced projects in this area, especially by working with development agencies in the regions. For example, it is seen that Bağcılar Bayrampaşa and Ümraniye Municipalities in Istanbul have a cooperation with the Istanbul Development Agency. There is also a project on the education of talented children who are supported by the Kahramanmaraş Elbistan Governorship and the Provincial National Education Directorate and the Eastern Mediterranean Development Agency.

\section{Conclusion and Recommendations}

When it comes to the definition of giftedness/talentedness, it is still seen that its scope is highly discussed and a wide variety of definitions are emphasized. It can be argued that this is because of scientists working on both the historical process and the gifted/talented person, and defining giftedness/intelligence according to their own viewpoints. However, when it comes to the generally accepted definitions in Turkey, students' differences from their peers and the ability over average are the common points of all definitions.

Gifted and talented individuals appear to have begun to be educated historically for the first time in the Ottoman Empire with the application of Palace Schools. In the Republican period, it has been emphasized that more and more gifted/talented individuals have been given more importance over the years. Therefore, it can be said that educational opportunities for gifted/talented children and different possibilities are increasing gradually.

In Turkey, when the national legislation, the statutory decrees, the regulations, directives and decisions were examined it is seen that there are articles that define and support the education of the gifted/talented children. Some advantages are provided including early start and promoting, that is, acceleration strategy. However, it is seen that different approaches such as course credit, credit completion are overlooked. In addition, in relation to the giftedness/talentedness, in primary and secondary education legislations, applications such as enrichment, differentiation, and support room are allowed but it is seen that the education of the gifted/talented children is tried to be carried out with the BILSEM model, commonly. These students need their own programs so that they do not have normal learning speed and features. It is clear that applications such as BILSEMs, which requires to use out of school time, will not be enough for these programs. However, in order to meet the educational needs of gifted and talented children, a sub-commission was created in the Turkish Grand National Assembly and the issue was examined in detail. AAAS's academic, financial and moral support was provided to improve the abilities of these children, and strategic plans have been prepared.

From the 1990s, gifted/talented children are beginning to be discussed and on the agenda topics in many areas in Turkey. In this regard, it is observed that the education of gifted and talented children is being discussed in detail in the universities and the Ministry of National Education, and efforts are being made to implement new programs for gifted/talented children by conducting various workshops and congresses. In parallel with the increasing awareness in the society in 2000s, it seems that institutions and centers related to the education of especially the gifted/talented children are beginning to be established, along with the pace of their work with the foundations and associations established by the parents of the children, in the public-local administrators, universities and non-governmental organizations. However, despite all the above-mentioned studies, it seems that there are various problems in the education of the gifted/talented children and the support of the special areas.

In order to solve the problems of gifted/talented children in Turkey, it is first necessary to establish a government policy on education of gifted/talented children. However, from the beginning of the Republican period, it has been observed that various training programs for the education of gifted/talent children have been implemented but have been abolished without evaluating 
the results. Stability and sustainability are extremely important in the education of gifted/talented children, as in the general education systems. Gifted and talented children will be able to access the education they need if the necessary programs are monitored and evaluated and necessary arrangements are made.

Raising awareness of families and society is the most important problem in the identification and education of gifted/talented children. For gifted/talented children, the government has to provide a whole range of services, which takes into account the health, nutrition and education of the child which are the fundamental philosophy of the early childhood approach as a whole and takes the potential to the maximum level, taking into account the principles of early identification and early education.

Especially in Turkey, it is seen that gifted/talented children have a broad right in the legal sense. However, it is also a fact that the use of these rights is very problematic. It should be noted that all kinds of measures should be taken for the children who are determined to be gifted/talented in the preschool period, supportive education rooms should be established. It is seen that there are regulations about the science art centers to provide education for pre-school children, however it seems that there are no sufficient practices. In this regard, especially considering the diversity of the gifted/talented children's characteristics, programs should be included in different educational programs as much as possible and should be expanded after pilot studies and necessary evaluations should be made. The necessity of diversification of education models and programs that will be prepared is very important because the skills and knowledge of children gradually grow and separate from their peers in the secondary and high school period. Supportive measures for children's skills, interests and abilities such as taking an active role in projects planned and implemented by separate schools, boarding schools, resource centers, governmental or private institutions, etc., should be taken by taking into account the breadth of the area of interest of children.

The strategic plan prepared in 2009 and 2013 in cooperation with the Ministry of National Education and AAAS was an extremely important development. However, it is unfortunately not possible to say that much has been done about the actions to be taken in this short, medium and long term. One of the important actions emphasized in these documents is the development of education models starting from the pre-school period to include higher education and later or adaptation of the models applied in other countries. At this point, it is seen that the current characteristics of Anatolian and science high schools are incompatible with those of their establishment and highly in erosion in terms of educational quality, and student and teacher characteristics due to the fact that they were spread rapidly. In these schools, it is necessary to make improvements especially for the election and education of the gifted children.

One of the elements that have indispensable importance in the education of gifted/talented children is the teachers who will educate these children. In Turkey, as mentioned above, departments were established in some universities, some of them provide only undergraduate education, while only one of them provides postgraduate education. It is seen that these departments started produce graduates after 2000 but the Ministry of Education assigned these teachers as a "class teacher" and did not open a separate teaching field as "gifted/talented teaching". When the studies conducted in other countries were examined, it is seen that the teachers who have graduated from various teaching areas have gained the right of teaching this area by participating in certificate programs on the education of gifted/talented children in accordance with certain criteria. It would be more appropriate for Turkey that needs to use its resources efficiently, to educate teachers who have graduated from various teaching fields and who have specific experience and certain special criteria, with certificate programs administered by field specialist academics instead of opening undergraduate programs. However, in order to provide the education that gifted/talented children need in different educational stages, it will be useful to spread the postgraduate education programs in universities provide opportunities for teachers and the researchers in order to train themselves in this field.

As a result, individuals who do not have the education and employment opportunities appropriate to their interests, abilities 
and skills are going to other countries offering these opportunities. Therefore, we are confronted with "brain drain" if we do not offer appropriate training opportunities for gifted/talented individuals and if we do not provide job opportunities afterwards. This situation is a great loss both in terms of the value given to the people in the society as well as being one of the biggest defeats in the development and progress of the country.

\section{References}

Akarsu, F. (2001). Üstün yetenekli çocuklar aileleri ve sorunları. Ankara: Eduser.

Akkutay, Ü.(1984). Enderun Mektepleri. Gazi Üniversitesi Yayınları. Ankara.

Akyüz, Y. (2008). Türk eğitim tarihi: MÖ 1000MS 2008 (12.Baskı). Ankara: Pegem Akademi.

Ataman, A. (2014). Giriş. A. Ataman (Ed.). Üstün zekâlılar ve üstün yetenekliler konusunda bilinmesi gerekenler (1.Baskı). Ankara: Vize.

Bakioğlu, A. ve Levent, F. (2013). Üstün Yeteneklilerin Eğitiminde Türkiye İçin Öneriler,

Üstün Yetenekli Eğitimi Araştırmaları Dergisi, 1(1), 31-44.

Çetinkaya, Ç. \& Döner, ì. (2012). Türkiye'de üstün yetenekliler tanınan hakların incelenmesi. Sakarya University Journal of Education, 2(3), 7-20.

Çetinkaya, N. (1998). Öğretmenlerin ve öğrencilerin çocuk haklarına bakışının değerlendirilmesi. Yüksek lisans tezi. Marmara Üniversitesi, 241s., İstanbul.

Dağlıŏlu H. E. (2014). Türkiye'de Üstün Yeteneklilik Eğitiminin Durumu. Yeni Türkiye Dergisi. (59) Temmuz-Ağustos 14131424.

Davaslıgil, Ü. (2004). Erken çocuklukta üstün zekâlı çocuklara uygulanacak farklılaşmış eğitim programı. 1. Türkiye Üstün Yetenekli Çocuklar Kongresi (23-25 Eylül 2004). Seçilmiş Makaleler Kitabı, s: 289300. İstanbul.

Devlet Planlama Teşkilatı (1963). Kalkınma planı (Birinci beş yıl) 1963-1967. http://www.kalkinma.gov.tr/Lists/Kalkn ma\%20Planlar/Attachments/9/plan1.pdf adresinden alınmıştır.

Devlet Planlama Teşkilatı (1973). Üçüncü beş yıllık kalkınma planı, 1973-1977. http://www.kalkinma.gov.tr/Lists/Kalkn
ma\%20Planlar/Attachments/7/plan3.pdf adresinden alınmıştır.

Devlet Planlama Teşkilatı (1979). Dördüncü Beş yıllık kalkınma planı 19791983.http://www.kalkinma.gov.tr/Lists/ Kalknma\%20Planlar/Attachments/6/plan4.pdf adresinden alınmıştır.

Devlet Planlama Teşkilatı (1990). Beşinci beş yıllık kalkınma planı 1985-1989. http://www.sp.gov.tr/upload/xSPTemel Belge/files/6Lvai+plan5.pdf adresinden alınmıştır.

Devlet Planlama Teşkilatı (1996). Altıncı beş yıllık kalkınma planı (19901994).http://www.kalkinma.gov.tr/Lists/ Kalknma\%20Planlar/Attachments/4/plan6.pdf adresinden alınmıştır.

Devlet Planlama Teşkilatı (2001). Yedinci beş yıllık kalkınma planı (1996-2000). http://www.sp.gov.tr/upload/xSPTemel Belge/files/20t9M+plan7.pdf adresinden alınmıştır.

Devlet Planlama Teşkilatı (2007). http://www.kalkinma.gov.tr/Lists/Kalkn ma\%20Planlar/Attachments/1/Ninth\%2 0 Development \%20Plan\%2020072013.pdf

Devlet Planlama Teşkilatı (2012). https://pbk.tbmm.gov.tr/dokumanlar/ka Ikinma-plani-9-genel-kurul.pdf adresinden alınmıştır.

Enç M. (1979). Üstün beyin gücü "Gelişim ve Eğitimleri". Ankara Üniversitesi Eğitim Bilimleri Fakültesi Yayınları No:83. Ankara Üniversitesi Basımevi. Ankara.

Enç, M., Çağlar, D. ve Özsoy, Y. (1975). Özel eğitime giriş. Ankara: Ankara Üniversitesi Eğitim Fakültesi Yayınları No:49 Kalite Matbaası.

Gagne, F. (1991). Toward a differential model of giftedness and talent. In N. Colangelo \& G. A. Davis (Eds.), Handbook of gifted education (pp.85-92). Boston, MA: Allyn \& Bacon.

Gardner H. (1983). Frames of mind. New York ; Basic Books.

Gardner H.(1991). The unschooled mind: How children think and how schools should teach. New York: Basic Books.

Güven, i. (2012). Türk eğitim tarihi. Edirne: Paradigma Kitabevi Yayınları.

http://www.tuzyeksav.org.tr/ 
http://www.bursabilimmerkezi.org/sayfa/tubi tak-ustun-zekalilar-ve-yeteneklilerakademisi/ 61.htm

http://www.meb.gov.tr/ozel-yetenekliogrenciler-icin-yeni-stratejilerhazirlandi/haber/9893/tr.

http://www.tacved.org/ustun-yeteneklilericin-dernekler-vakiflar

Kepenekci, Y. K. (2014). Eğitimciler için insan hakları ve vatandaşlık (Gözden geçirilmiş ve genişletilmiş ikinci baskı). Ankara: Siyasal.

Kırpık, G.; Ünal, U.; Işık, H., Demirtaş, B., Tokdemir, M. A.; Birbudak, T. S. ve Akyol, H. (2016). Türk eğitim tarihi el kitabı (Birinci baskı). Ankara: Grafiker.

Kili, S. ve Gözübüyük, A. Ş. (2000). Sened-i ittifak'tan günümüze Türk anayasa metinleri. İstanbul: Türkiye İş Bankası Kültür Yayınları.

Küçükoğlu, M. (2014). Üstün ve özel yetenekli ögrrencilerin eğitiminde model olan Beyazıt Ford Otosan Ilköğretim Okulu üzerine bir araştırma. Yüksek Lisans Tezi İstanbul Sebahattin Zaim Üniversitesi Sosyal Bilimler Enstitüsü. İstanbul.

Levent, F. (2011). Üstün yetenekli çocukların hakları el kitabı: Anne-baba ve öğretmenler için. İstanbul: Çocuk Vakfı Yayınları.

Levent, F. (2014). Üstün yetenekli çocukları anlamak: Üstün yetenekli çocuklar sarmalında aile, eğitim sistemi ve toplum (Geliştirilmiş üçüncü basım). Ankara: Nobel.

Marland, S. (1972). The education of the gifted and talented (vol 1). Washington D.C.: Government Printing Office. U.S.:Commissoner of education.

MEB (1991a). 1. Özel eğitim konseyi ön raporu. Ankara: MEB Yayımlar Dairesi Başkanlığı.

MEB (1991b). 19. Millî Eğitim Şûrası sona erdi. http://www.meb.gov.tr/19-mill-egitimsrasi-sona-erdi/haber/7594/tr adresinden alınmıştır. http://www.resmigazete.gov.tr/eskiler/ 2015/06/20150625-3.htm.

MEB (2003). İlköğretim Yöneltme Yönergesi. Tebliğler Dergisi 04.10.2016 tarihinde http://mevzuat.meb.gov.tr/html/2552_ $0 . h t m l$ adresinden alınmıştır. MEB

(2010b). http://tkb.meb.gov.tr/meb_iys_dosyalar /2014_10/02113646_18_sura.pdf adresinden alınmıştır.

MEB (2010a). Üstün zekâlıların/yeteneklilerin eğitimi çalıştayı hazırlık dokümanı. Ankara: MEB Özel Eğitim Rehberlik ve Danışma Hizmetleri Genel Müdürlüğü Yayını.

MEB (2013). Okul Öncesi Eğitimi Programı

MEB

http://mebk12.meb.gov.tr/meb_iys_dos yalar/35/27/719973/dosyalar/2015_ 02/02041116_19.millieitimuraskararlar. pdf

MEB (2015). Milli Eğitim İstatistikleri Örgün Eğitim 2014-2015.

MEB(1982).http://ttkb.meb.gov.tr/meb_iys_d osyalar/2014_10/02113508_11_sura.pdf

$\operatorname{MEB}(1988)$. http://ttkb.meb.gov.tr/meb_iys_dosyala r/2014_10/02113522_12_sura.pdf

$\operatorname{MEB}(2006 b)$. http://ttkb.meb.gov.tr/meb_iys_dosyala r/2014_10/02113522_12_sura.pdf

MEB. (2006a). Özel Eğitim Hizmetleri Yönetmeliği. Ankara: Milli Eğitim Basımevi.

MEB. (2007). Bilim ve Sanat Merkezleri Yönergesi. Tebliğler Dergisi, 2593.

MEB. (2010). Üstün zekâlıların/yeteneklilerin eğitimi çalıştayı (Hazırlık dokümanı). Ankara: Özel Eğitim Rehberlik ve Danışma Hizmetleri Genel Müdürlüğü.

Morelock, M. (1992). “Giftedness: The view from within" Understanding Our Gifted 4 (3), 1, 11-15.

Özbay, Y. (2013). Üstün yetenekli çocuklar ve aileleri. T.C. Aile ve Sosyal Politikalar Bakanlığı Aile ve Toplum Hizmetleri Genel Müdürlüğü, Ankara.

Özbay, Y., Metin, N., Dağlıoğlu, H.E., Çalışandemir, F., Bencik Kangal, S. Ve Alemdar, M. (2009). Model Development for Inclusive Gifted Education in Turkey. $12^{\text {th }}$ Inclusive Education in the Balkan Countries: Policy and Practice 25-27 June 2009 Ohrid-Makedonya. Publishing House Kyriakidis Brothers s.a. pp:245-251.

Özsoy, Y., Özyürek, M. ve Eripek, S. (1989). Özel Eğitime Muhtaç Çocuklar "Özel Eğitime Giriş" Karatepe Yayınları. Genel No:7, Özel No:6, Ankara.

Renzulli, J. S. (1986). The treering conception of giftedness: A developmental model for creative productivity. conception of giftedness. Cambridge: Press Syndicate of University of Cambridge. 
Resmi Gazete (1929). 1416 sayılı Ecnebi Memleketlere Gönderilecek Talebe Hakkında Kanun, 1169, 16 Nisan 1929.

Resmi Gazete (1943). 4489 sayılı Yabancı Memleketlere Gönderilecek Memurlar Hakkında Kanun. 5512, 20 Eylül 1943.

Resmi Gazete (1948). 5245 sayılı Îdil Biret ve Suna Kan'ın Yabancı Memleketlere Müzik Tahsiline Gönderilmesine Dair Kanun. 6955, 12 Temmuz 1948.

Resmi Gazete (1956). 6660 sayılı Güzel Sanatlarda Fevkalâde İstidat Gösteren Çocukların Devlet Tarafından Hakkında Kanun. 9242, 24 Şubat 1956.

Resmi Gazete (1961). 222 sayılı Illköğretim ve Eğitim Kanunu. 10705, 12 Ocak 1961.

Resmi Gazete (1973).1739 sayılı Milli Eğitim Temel Kanunu. 14574, 24 Haziran 1973.

Resmi Gazete (1982). 2709 sayılı Türkiye Cumhuriyeti Anayasası. 7 Kasım 1982.

Resmi Gazete (1983). 2916 sayılı Özel Eğitime Muhtaç Çocuklar Kanunu.18192, 15Ekim 1983.

Resmi Gazete (1997). 573 sayılı Özel Eğitim Hakkında Kanun Hükmünde Kararname. 23011, 6 Haziran 1997.

Resmi Gazete, (2015). Okul Öncesi ve Ilköğretim Kurumları Yönetmeliği

Sak, U. (2009). Üstün yetenekliler eğitim programları. Ankara: Maya Akademi.
Sarıhan, Z. (2009). 1921 Maarif kongresi. Ankara: Milli Eğitim Bakanlığı Yayınları.

Sternberg, R. J. (2007). Finding students who are wise, practical, and creative. The Chronicle of Higher Education, 53 (44),11-13.

TBMM (2012). Üstün yetenekli çocukların keşfi, eğitimleriyle ilgili sorunların tespiti ve ülkemizin gelişimine katkı sağlayacak etkin istihdamlarının sağlanması amacıyla meclis araştırma komisyonu raporu. http://www.tbmm.gov.tr/sirasayi/done m24/yil01/ss427.pdf Erişim tarihi: 10.05.2014.

Terman, L. M. (1925).Mental and Physical Traits of a Thousand Gifted Children: Genetic Studies of Genius, vol. 1, Standfort University Press, Standfort, Calif, USA.

Turupcu, A. \& Gültekin Akduman, G. (2009). Okul Öncesi Eğitim ve Çocuk Hakları (12. Bölüm). G. Uyanık Balat (ed.) Okul Öncesi Eğitime Giriş (s. 235-251). Ankara: Nobel.

TÜBiTAK, (2013). Üstün Yetenekli Bireyler Strateji Ve Uygulama Planı 2013 - 2017 Bilim ve Teknoloji Yüksek Kurulu http://www.tubitak.gov.tr/sites/default/ fi-

les/meb_ustunyeteneklibireyler_sunum _15012013.pdf. Erişim tarihi: 01.05.2014 